\title{
Suitability of novel galactomannans as edible coatings for tropical fruits
}

\author{
Miguel A. Cerqueira ${ }^{a}$, Álvaro M. Lima ${ }^{\mathrm{b}}$, José A. Teixeira ${ }^{\mathrm{a}}$, Renato A. Moreira ${ }^{\mathrm{c}}$, António A. Vicente ${ }^{\mathrm{a}, *}$ \\ ${ }^{a}$ IBB - Institute for Biotechnology and Bioengineering, Centre of Biological Engineering, University of Minho, Campus de Gualtar, 4710-057 Braga, Portugal \\ ${ }^{\mathrm{b}}$ Departamento de Bioquímica e Biologia Molecular, Federal University of Ceará, Campus do Pici, CEP 60451-970 Fortaleza, CE, Brazil

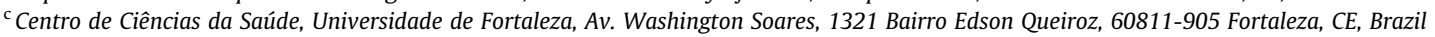

\section{A R T I C L E I N F O}

\section{Article history:}

Received 9 August 2008

Received in revised form 25 March 2009

Accepted 4 April 2009

Available online 16 April 2009

\section{Keywords:}

Edible coatings

Edible films

Galactomannans

Wettability

Tropical fruits

\begin{abstract}
A B S T R A C T
The main objective of this work was to determine the optimal composition of edible coatings in view of their application to extend the shelf life of several tropical fruits. Coatings constituted by galactomannans from different sources (Caesalpinia pulcherrima and Adenanthera pavonina) and glycerol were characterized as coatings for five tropical fruits: acerola (Malpighia emarginata), cajá (Spondias lutea), mango (Mangifera indica), pitanga (Eugenia uniflora) and seriguela (Spondias purpurea). The surface properties of the five fruits were determined and different aqueous galactomannan solutions $(0.5 \%, 1.0 \%$ and $1.5 \%)$ with glycerol $(1.0 \%, 1.5 \%$ and $2.0 \%)$ were tested for their wettability on fruits. For the solutions having a better wettability, films were casted and water vapour permeability, oxygen permeability, carbon dioxide permeability, tensile strength and elongation at break were determined. Taking into account the surface and permeability properties of the obtained films, four compositions were selected as the best coatings to the studied fruits: acerola $-0.5 \%$ of $A$. pavonina galactomannan and $1.0 \%$ of glycerol; cajá $1.0 \%$ of A pavonina galactomannan and $1.0 \%$ of glycerol; mango and pitanga $-1.5 \%$ of $A$. pavonina galactomannan and $1.0 \%$ of glycerol; and seriguela $-0.5 \%$ of $C$. pulcherrima galactomannan and $1.5 \%$ of glycerol. For the coating, the values of the measured properties were as follows: wettability ranged from $-36.33 \pm 3.39$ to $-26.45 \pm 4.58 \mathrm{mN} \cdot \mathrm{m}^{-1}$; water vapour permeability ranged from $4.89 \pm 0.11$ to $6.25 \pm 0.20 \times 10^{-11} \mathrm{~g} \mathrm{~m}^{-1} \mathrm{~s}^{-1} \mathrm{~Pa}^{-1}$; oxygen permeability ranged from $0.31 \pm 0.01$ to $0.99 \pm 0.13 \times 10^{-15}$ $\mathrm{g} \mathrm{m}(\mathrm{Pa} \mathrm{s} \mathrm{m})^{2}$; carbon dioxide permeability ranged from $28.81 \pm 3.08$ to $61.19 \pm 1.44 \times 10^{-15} \mathrm{~g} \mathrm{~m}$ $\left.(\mathrm{Pa} \mathrm{s} \mathrm{m})^{2}\right)^{-1}$; tensile strength ranged from $2.56 \pm 0.15$ to $3.96 \pm 0.43 \mathrm{MPa}$; and elongation at break ranged from $28.26 \pm 4.53 \%$ to $46.36 \pm 2.29 \%$.
\end{abstract}

(c) 2009 Elsevier Ltd. All rights reserved.

\section{Introduction}

During the last decades, there has been an increasing demand for fresh fruits and vegetables forcing the food industry to develop new and better methods for maintaining food quality and extending shelf life. Great losses (from $20 \%$ to $80 \%$ ) in the quality of fresh fruits occur from harvesting to final consumption and the fruits short shelf life is an important drawback concerning distribution chains. On the other hand, consumers around the world demand food of high quality, without chemical preservatives and with extended shelf life. As a consequence, an increased effort has been made to discover new natural preservatives and antimicrobials (Chien et al., 2007).

Packaging plays a decisive role in the improvement of fruits' shelf life and new packaging materials are being developed, most of them are derived from renewable resources (Lin and Zhao, 2007). Edible coatings act by creating a modified atmosphere surrounding the commodity, similar to that achieved by controlled or modified atmospheric storage conditions. The modified atmo-

\footnotetext{
* Corresponding author. Tel.: +351 253604 419; fax: +351 253678986

E-mail address: avicente@deb.uminho.pt (A.A. Vicente).
}

sphere created by edible coatings protects the food from the moment it is applied until it reaches the final consumer (Diab et al., 2001; Durango et al., 2006; Ribeiro et al., 2007).

Several researchers studied the application of coatings in fruits such as apples (Rojas-Grau et al., 2007), strawberries (Mali and Grossmann, 2003; Tanada-Palmu and Grosso, 2005; Ribeiro et al., 2007), mango (Srinivasa et al., 2002; Chien et al., 2007; Dang et al., 2008) and kiwi (Xu et al., 2001). Polysaccharide-based coatings are colourless and have an oil-free appearance, and can be used to increase the shelf life of fruits, vegetables, shellfish or meat products to avoid dehydration, and to reduce the oxidative rancidity and darkening of the surface to some extent. Other characteristics that make them attractive are their transport properties (permeability to $\mathrm{CO}_{2}, \mathrm{O}_{2}$ and water vapour), the reduction of materials weight loss and the reduction of the microbial spoilage of the fruits (Petersen et al., 1999; Dang et al., 2008). However, the effectiveness of edible coatings for fruits preservation depends, in a first stage, on the control of the wettability of the coating in order to ensure a uniformly coated surface. Other factors also affect the effectiveness of the coating, such as transport (permeability) and mechanical properties; these must also be considered in order to: 
- Decrease the water loss in the fruits (i.e., lower water vapour permeability values).

- Decrease the $\mathrm{O}_{2}$ permeability (i.e., lower $\mathrm{O}_{2}$ permeability values) as a lower $\mathrm{O}_{2}$ concentration prolongs the shelf life by delaying the oxidative breakdown of the complex substrates (Farber et al., 2003), and reduce the production of ethylene, a key element of the ripening and maturation process (Lee et al., 1996; Zagory, 1995).

- Increase the shelf life of fruits, by increasing the lag-phase and generation time during the logarithmic growth phase of spoilage microorganisms (Farber et al., 2003; Phillips, 1996), which is accomplished by keeping high $\mathrm{CO}_{2}$ permeability values.

- Improve the mechanical resistance of the films/coatings in order to preserve their integrity as much as possible during the fruits' shelf life.

Galactomannans are present in the endosperm of numerous plants, particularly the Leguminosae, and they have several functions, including being a reserve of carbohydrates (Reid and Edwards, 1995). Galactomannans are polysaccharides built up of a $\beta-(1-4)$-D-mannan backbone with single D-galactose branches linked $\alpha-(1-6)$. Their mannose/galactose $(M / G)$ ratios differ according to the species (Kök et al., 1999). Galactomannans can often be used in different forms for human consumption. Featuring different physicochemical properties, galactomannans are a versatile material used for many applications: they are excellent stiffeners and stabilizers of emulsions, and the absence of toxicity allows their use in the textile, pharmaceutical, biomedical, cosmetics and food industries (Srivastava and Kapoor, 2005; Vieira et al., 2007).

In this work, coatings of galactomannans from two plant species (Adenanthera pavonina and Caesalpinia pulcherrima) were evaluated. A. pavonina, a plant from the Leguminosae family, native from tropical Asia, is used in reforestation and as an ornamental plant and is also an important source of wood. C. pulcherrima is also a plant from the Leguminosae family being found throughout India and other regions of the globe where it is used as an ornamental plant. Galactomannan from $A$. pavonina presents a ratio mannose/galactose of 1.35 , while the galactomannan obtained by $C$. pulcherrima seeds presents a ratio mannose/galactose of 2.88 (Cerqueira et al., 2009). These polysaccharides are a cheap alternative to the existing (mostly synthetic) substances and have the advantage of being produced locally, near the harvesting sites of the studied fruits. The development of these applications from natural products and their use in the production sites to increase the fruits' shelf life can be an important contribution to the economy of countries such as Brazil.

This work aims at assessing the suitability of galactomannans from seeds of $A$. pavonina and $C$. pulcherrima to be used as edible coatings for different tropical fruits: acerola (Malpighia glabra), cajá (Spondias lutea), mango (Mangifera indica), pitanga (Eugenia uniflora) and seriguela (Spondias purpurea) and to determine which formulation is the most adequate to coat these fruits. This has been done by evaluating the fruits' surface properties following the application of different coatings (formed by mixtures of each of the polysaccharides at different concentrations and plasticizer) and by optimizing the composition of the coating in terms of its wettability and permeability properties. To evaluate the mechanical properties of the selected coatings the tensile strength and elongation at break were measured.

\section{Materials and methods}

\subsection{Raw material}

The seeds of A. pavonina (AP) and C. pulcherima (CP) were collected in the Federal University of Ceará, Campus of Pici, Fortaleza,
CE - Brazil during January 2006 and after being cleaned they were maintained in a cool, dry place until further use.

The polysaccharide extraction was performed as described in Cerqueira et al. (2009). The seeds were removed from the pods, cleaned and placed in a blender, where they were mechanically broken. Following this, the endosperm was manually separated from the germ and the hull and was suspended in ethanol (purity $99.8 \%$, Riedel-de Haën, Germany) at $70{ }^{\circ} \mathrm{C}$ for $15 \mathrm{~min}$. The ethanol was decanted, distilled water was added in a 1:5 (endosperm:water), this suspension was left to rest for approximately $24 \mathrm{~h}$. Water in a 1:10 (suspension:water) volumetric ratio was added and the obtained suspension was mixed in a blender for $5 \mathrm{~min}$. The blended suspension was filtered through a nylon net followed by a centrifugation step at $3800 \mathrm{~g}$ (Sigma $4 \mathrm{~K}$, B. Braun, Germany) for $20 \mathrm{~min}$ at $20^{\circ} \mathrm{C}$. The precipitation of the galactomannan was achieved by adding the supernatant to ethanol (purity $99.8 \%$, Riedel-de Haën, Germany) at a ratio of $1: 2$. The ethanol was decanted and the precipitated galactomannan was lyophilized (Christ, alpha $2-4$, Germany) and maintained in a dry place until further use.

The materials used to prepare the edible coating solutions were: galactomannan (as extracted from A. pavonina and C. pulcherrima seeds), glycerol 87\% (Gly) (Panreac, Spain) and distilled water.

\subsection{Coatings and films preparation}

The coating formulations were based in a three-level factorial design with galactomannan concentrations of: $0.5 \%, 1.0 \%$ and $1.5 \%(\mathrm{w} / \mathrm{v})$ and glycerol concentrations of: $1.0 \%, 1.5 \%$ and $2.0 \%(\mathrm{v} /$ $v)$. The number of replications is specified when describing each of the methodologies used. The concentrations were chosen based on preliminary experiments (data not shown) where it was determined that for galactomannan contents above $1.5 \%(\mathrm{w} / \mathrm{v})$ their dissolution was extremely difficult; also for glycerol, previous studies indicated that a maximum of $2.0 \%$ would be necessary, while for values lower than $0.5 \%$ the film would be too brittle.

The coating solutions were prepared by dissolving the lyophilized galactomannan in distilled water $\left(20^{\circ} \mathrm{C}\right)$ and addition of the plasticizer. Each mixture was stirred for $2 \mathrm{~h}$ at room temperature $\left(20^{\circ} \mathrm{C}\right)$ and left to stabilize for 10 more minutes at the same temperature. The films were prepared with a constant amount $(28 \mathrm{~mL})$ of solution which was cast onto a $9 \mathrm{~cm}$ diameter glass plate. The films were dried in an oven at $35^{\circ} \mathrm{C}$ for $16 \mathrm{~h}$ and maintained at $20^{\circ} \mathrm{C}$ and 50\% $\mathrm{RH}$ until their characterization.

\subsection{Fruits and their preparation for contact angle measurements}

Acerola, pitanga, seriguela, cajá and mango were purchased from a local supermarket (Fortaleza, CE - Brazil). All fruits were maintained at $8-10{ }^{\circ} \mathrm{C}$ until further use. The fruits were selected for their uniformity, size, colour (paying particular attention at their ripeness state) and the absence of damage and fungal infection. Before testing, the fruits were left at room temperature $\left(20^{\circ} \mathrm{C}\right)$ and their surface was cleaned with distilled water. Thin portions of the outer surface (skin) of the fruits were cut with a knife and placed on a glass plate for contact angle measurements.

\subsection{Critical surface tension of fruits skins}

According to Zisman (1964), in systems having a surface tension lower than $100 \mathrm{mN} \mathrm{m}^{-1}$ (low-energy surfaces), the contact angle formed by a drop of liquid on a solid surface will be a linear function of the surface tension of the liquid, $\gamma_{L V}$, (where phase $V$ is air saturated with the vapour of liquid, $L$ ). The Zisman method is applicable only for low-energy surfaces; therefore it is necessary to determine the surface energy of the fruits. 
For a pure liquid, if polar $\left(\gamma_{L}^{P}\right)$ and dispersive $\left(\gamma_{L}^{d}\right)$ interactions are known, and if $\theta$ is the contact angle between that liquid and a solid, the interaction can be described in terms of the reversible work of adhesion, $W_{a}$, as:

$W_{a}=W_{a}^{d}+W_{a}^{p} \Longleftrightarrow W_{a}=2 \cdot\left(\sqrt{\gamma_{S}^{d} \cdot \gamma_{L}^{d}}+\sqrt{\gamma_{S}^{p} \cdot \gamma_{L}^{p}}\right)$

where $\gamma_{s}^{P}$ and $\gamma_{s}^{d}$ are the polar and dispersive contributions of the surface of the studied solid. Rearranging Eq. (1), yields:

$\frac{1+\cos \theta}{2} \cdot \frac{\gamma_{L}}{\sqrt{\gamma_{L}^{d}}}=\sqrt{\gamma_{S}^{p}} \cdot \sqrt{\frac{\gamma_{L}^{p}}{\gamma_{L}^{d}}}+\sqrt{\gamma_{S}^{d}}$

The contact angle determinations (please see Section 2.5) of at least three pure compounds: bromonaphthalene (Merck, Germany), formamide (Merck, Germany) and ultra pure water, on the surface of the fruit (fruit skin) combined with the each dispersive and polar component value, will allow the calculation of both the independent variable, $\left(\sqrt{\frac{\gamma_{L}^{p}}{\gamma_{L}^{d}}}\right)$, and the dependent variable, $\left(\frac{1+\cos \theta}{2} \cdot \frac{\gamma_{L}}{\sqrt{\gamma_{L}^{d}}}\right)$, from Eq. (2).

The surface tension, the dispersive and the polar component were, respectively, $72.10,19.90$ and $52.20 \mathrm{mN} \mathrm{m}^{-1}$ for water, $44.40,44.40$ and $0.00 \mathrm{mN} \mathrm{m}^{-1}$ for bromonaphthalene and 56.90, 23.50 and $33.40 \mathrm{mN} \mathrm{m}^{-1}$ for formamide (Busscher et al., 1984).

The estimation of the critical surface tension $\left(\gamma_{C}\right)$ was performed by extrapolation from Zisman plots (Zisman, 1964). Zisman plots have long been used to characterize the wettability of lowenergy surfaces. Zisman plots are obtained by plotting the cosine of the contact angle of pure liquids on a solid surface to be studied against the surface tension of the same series of liquids. The intercept of these curves with $\cos \theta=1$ is known as the critical surface tension $\left(\gamma_{C}\right)$. The critical surface tension is an imaginary point of the $\gamma_{s v}$ value and it is frequently used to describe the wettability of a surface. It represents the value of $\gamma_{L V}$ of a liquid above which the spreading of this liquid in a solid surface is complete. The critical surface tension $\left(\gamma_{C}\right)$ is defined as:

$\gamma_{C}=\lim \gamma_{L V}$ as $\theta \rightarrow 0$

\subsection{Wettability}

The wettability was studied by determining the values of the spreading coefficient $\left(W_{s}\right)$ and the works of adhesion $\left(W_{a}\right)$ and cohesion $\left(W_{c}\right)$. The adhesive forces promote the liquid spreading in a solid surface and the cohesive forces promote their contraction. The wetting behaviour of the solutions will mainly depend on the balance between these forces. The surface tension of the coating solution was measured by the pendant drop method using the Laplace-Young approximation (Song and Springer, 1996).

The contact angle $(\theta)$ of a liquid drop on a solid surface is defined by the mechanical equilibrium of the drop under the action of three interfacial tensions: solid-vapour $\left(\gamma_{S V}\right)$, solid-liquid $\left(\gamma_{S L}\right)$, and liquid-vapour $\left(\gamma_{L V}\right)$. The equilibrium spreading coefficient $\left(W_{s}\right)$ is defined by Eq. (4) (Rulon and Robert, 1993) and can only be negative or zero:

$W_{s}=W_{a}-W_{c}=\gamma_{S V}-\gamma_{L V}-\gamma_{S L}$

where $W_{a}$ and $W_{c}$ are the works of adhesion and cohesion, defined by Eqs. (5) and (6), respectively

$W_{a}=\gamma_{L V}+\gamma_{S V}-\gamma_{S L}$

$W_{c}=2 \cdot \gamma_{L V}$
Contact angle $(\theta)$ and liquid-vapour surface tension $\left(\gamma_{L V}\right)$ were measured in a face contact angle meter (OCA 20, Dataphysics, Germany). The samples of the coatings were taken with a $500 \mu \mathrm{L}$ syringe (Hamilton, Switzerland), with a needle of $0.75 \mathrm{~mm}$ of diameter. The contact angle at the fruit surfaces was measured by the sessile drop method (Newman and Kwok, 1999), in which a droplet of the tested liquid was placed on a horizontal surface and was observed with a face contact angle meter. Measurements were made in less than $30 \mathrm{~s}$. Ten replicates of contact angle and surface tension measurements were obtained at $21.3 \pm 0.5^{\circ} \mathrm{C}$.

\subsection{Film thickness}

The film thickness was measured with a digital micrometer (Mitutoyo, Japan). Five thickness measurements were taken on each testing sample in different, randomly chosen points. The mean value was used to calculate water vapour permeability $(W V P)$, oxygen permeability $\left(\mathrm{O}_{2} P\right)$, carbon dioxide permeability $\left(\mathrm{CO}_{2} \mathrm{P}\right)$ and tensile strength $(\mathrm{TS})$.

\subsection{Water vapour permeability measurement (WVP)}

The measurement of water vapour permeability (WVP) was determined gravimetrically based on ASTM E96-92 method (McHugh et al., 1993; Guillard et al., 2003). The film was sealed on the top of a permeation cell containing distilled water $\left(100 \% \mathrm{RH} ; 2337 \mathrm{~Pa}\right.$ vapour pressure at $\left.20^{\circ} \mathrm{C}\right)$, placed in a desiccator at $20^{\circ} \mathrm{C}$ and $0 \% \mathrm{RH}$ (0 Pa water vapour pressure) containing silica. The cells were weighed at intervals of $2 \mathrm{~h}$ for $10 \mathrm{~h}$. Steady-state and uniform water pressure conditions were assumed by maintaining the air circulation constant outside the test cell by using a miniature fan inside the desiccator (McHugh et al., 1993). The slope of weight loss versus time was obtained by a linear regression. Three replicates were obtained for each sample.

\subsection{Oxygen and carbon dioxide permeability}

Oxygen permeability $\left(\mathrm{O}_{2} \mathrm{P}\right)$ and carbon dioxide permeability $\left(\mathrm{CO}_{2} \mathrm{P}\right)$ were determined based on the ASTM D 3985-02 (2002) method. The films were sealed between two chambers, having each one two channels. In the lower chamber $\mathrm{O}_{2}$ (or $\mathrm{CO}_{2}$ ) was supplied at a controlled ( $\mathrm{J} \& \mathrm{~W}$ Scientific, ADM 2000, USA) flow rate to maintain its pressure constant in that compartment. The other chamber was purged by a stream of nitrogen, also at controlled flow. Nitrogen acted as a carrier for the $\mathrm{O}_{2}$ (or the $\mathrm{CO}_{2}$ ).

In the case of $\mathrm{O}_{2} \mathrm{P}$ measurement, the flow leaving this chamber was connected to an $\mathrm{O}_{2}$ sensor (Mettler Toledo, Suisse) which measured the $\mathrm{O}_{2}$ concentration in that flow on-line. In the case of $\mathrm{CO}_{2} P$ measurement the flow leaving this chamber was collected in a syringe for $\mathrm{CO}_{2}$ quantification. To determine $\mathrm{CO}_{2}$ concentration, $1 \mathrm{~mL}$ of sample was injected in a gas chromatograph (Chrompack 9001, Middelburg, Netherlands) at $110^{\circ} \mathrm{C}$ with a column Porapak Q 80/ 100 mesh $2 \mathrm{~m} \times 1 / 8^{\prime \prime} \times 2 \mathrm{~mm} \mathrm{SS}$, using a flame ionization detector (FID) at $110^{\circ} \mathrm{C}$. Helium at $23 \mathrm{~mL} \mathrm{~min}^{-1}$ was used as carrier gas. A standard mixture containing $10 \% \mathrm{CO}_{2}, 20 \% \mathrm{O}_{2}$ and $70 \% \mathrm{~N}_{2}$ was used for calibration.

The flows of the two chambers were connected to a manometer to ensure the equality of pressures (both at $1 \mathrm{~atm}$ ) between both compartments. As the $\mathrm{O}_{2}$ (and the $\mathrm{CO}_{2}$ ) was carried continuously by the nitrogen flow, it was considered that partial pressure of $\mathrm{O}_{2}$ (and the $\mathrm{CO}_{2}$ ) in the upper compartment is null, therefore $\Delta P$ is equal to $1 \mathrm{~atm}$. Three replicates were obtained for each sample, in each case $\left(\mathrm{O}_{2} \mathrm{P}\right.$ and $\left.\mathrm{CO}_{2} \mathrm{P}\right)$. 


\subsection{Mechanical properties - tensile strength (TS) and elongation at} $\operatorname{break}(E)$

TS and $E$ were measured with an Instron Universal Testing Machine (Model 4500, Instron Corporation) following the guidelines of ASTM D 882-91 (1991). The initial grip separation was set at $30 \mathrm{~mm}$ and the crosshead speed was set at $5 \mathrm{~mm} \mathrm{~min}^{-1}$. TS was expressed in MPa and was calculated by dividing the maximum load $(N)$ by the initial cross-sectional area $\left(\mathrm{m}^{2}\right)$ of the specimen. $E$ was calculated as the ratio of the final length at the point of sample rupture to the initial length of a specimen $(30 \mathrm{~mm})$ and expressed as a percentage. According to the ASTM standard, film strips with a length of $45 \mathrm{~mm}$ and a width of $20 \mathrm{~mm}$ were used. TS and $E$ tests were replicated ten times for each sample.

\subsection{Statistical analysis}

The statistical analyses of the data were performed using Analysis of Variance (ANOVA), Tukey mean comparison test $(p<0.05)$ and regression analysis (SigmaStat, trial version, 2003, USA).

\section{Results and discussion}

\subsection{Surface tension and critical surface tension of fruits skins}

The surface tension of the fruits is very similar, but there are differences between the polar and the dispersive components (Table 1). All the fruits present a higher dispersive component, which shows the ability of the fruit surface to participate in non-polar interactions. This was also demonstrated by Ribeiro et al. (2007) in strawberry, where the dispersive component was higher than the polar component. A surface with these characteristics interacts with liquid primarily by dispersion forces that can influence the effective spreading of the coating on the surface of the fruits: the compatibility of the polarity (apolar or polar) of the surface and of the coating may play therefore an important role in the wettability of a surface by a liquid and may condition the composition of the latter. In the present work, the fruits presenting the higher values of polar interactions were acerola and seriguela, while mango displayed the lowest value of the polar component, therefore pre- senting the lowest ability to participate in polar interactions. These differences, despite being statistically significant, are presumably not sufficient to impose a very different behaviour of the surface towards the coating solution. This hypothesis is supported by the results presented in, e.g. Table 2, where no clear difference is shown between the values of $W_{s}$ for the fruits and coatings evaluated in this work.

Table 1 also shows the value of the critical surface tension obtained for each fruit, which varies between 9.39 and $23.92 \mathrm{mN} \mathrm{m}^{-1}$. Acerola presented the lowest value and cajá the highest. The obtained values are close to the critical surface tension of the apple $\left(18.70 \mathrm{mN} \mathrm{m}^{-1}\right)$ and of the orange $\left(20.00 \mathrm{~m} \mathrm{~N} \mathrm{~m}^{-1}\right)$ presented by Choi et al. (2002), exception made to acerola and pitanga that present a lower value. Also, the values of the critical surface tension must be lower than the values of the surface tension (Dann, 1970), which holds true for all the fruits used in this study. In all cases, it is possible to conclude that the studied fruits have low-energy surfaces (i.e., below $100 \mathrm{mN} \mathrm{m}^{-1}$ ) meaning that the Zisman method is applicable.

\subsection{Wettability}

Wettability determinations were performed with different galactomannan concentrations for varying plasticizer concentrations. The wettability was studied by determining the values of the spreading coefficient $\left(W_{s}\right)$. The spreading coefficient $\left(W_{s}\right)$ of the solutions of galactomannans and glycerol applied on each fruit was analysed and presented in Tables 2 and 3. For each fruit, the best (higher) value of $W_{s}$ for the respective galactomannan was determined (Tukey test, $p<0.05$ ) and is filled in gray. When no statistically significant differences between galactomannan solutions are observed, it has been assumed that both were equally good in terms of wettability and that their differentiation must be made based on other criteria (such as permeability to gases, which will be presented subsequently).

The results show that the values of $W_{s}$ are quite dependent on both the source and concentration of galactomannan and the fruit tested. The solutions with lower values of A. pavonina (AP) galactomannan concentration present better (higher) values $(p<0.05)$ of $W_{s}$ for those fruits with higher values of the polar component (ace-

Table 1

Values of critical surface tension, surface tension and its polar and dispersive components for the analysed fruits.

\begin{tabular}{|c|c|c|c|c|}
\hline Fruit & Critical surface tension $\left(\mathrm{mN} \mathrm{m}^{-1}\right)$ & Surface tension $\left(\mathrm{mN} \mathrm{m}^{-1}\right)$ & Polar component $\left(\mathrm{mN} \mathrm{m}^{-1}\right)$ & Dispersive component $\left(\mathrm{mN} \mathrm{m}^{-1}\right)$ \\
\hline Acerola & $9.39 \pm 0.07^{\mathrm{a}}$ & $27.94 \pm 0.03^{\mathrm{a}}$ & $4.35 \pm 0.01^{\mathrm{a}}$ & $23.59 \pm 0.02^{\mathrm{a}}$ \\
\hline Cajá & $23.92 \pm 0.10^{\mathrm{b}}$ & $30.15 \pm 0.02^{b}$ & $2.29 \pm 0.01^{\mathrm{b}}$ & $27.86 \pm 0.01^{b}$ \\
\hline Mango & $22.68 \pm 0.09^{c}$ & $29.04 \pm 0.02^{\mathrm{c}}$ & $1.47 \pm 0.01^{\mathrm{c}}$ & $27.57 \pm 0.01^{\mathrm{c}}$ \\
\hline Pitanga & $13.42 \pm 0.09^{d}$ & $26.95 \pm 0.02^{d}$ & $3.07 \pm 0.01^{d}$ & $23.88 \pm 0.01^{d}$ \\
\hline Seriguela & $19.62 \pm 0.09^{\mathrm{e}}$ & $31.48 \pm 0.05^{\mathrm{e}}$ & $4.59 \pm 0.03^{e}$ & $26.89 \pm 0.02^{\mathrm{e}}$ \\
\hline
\end{tabular}

a-e Means $(n=10)$ in the same column with different superscripts are significantly different $(p<0.05)$.

Table 2

Spreading coefficient $\left(W_{s}\right)$ obtained for solutions of $A$. pavonina galactomannan and glycerol on the analysed fruits.

\begin{tabular}{|c|c|c|c|c|c|c|}
\hline Gal. (w/v) & Glycerol (v/v) & Acerola & Cajá & Mango & Pitanga & Seriguela \\
\hline 0.5 & 1.0 & $-29.92 \pm 2.10 a$ & $-36.50 \pm 3.05^{\mathrm{a}}$ & $-30.97 \pm 2.17^{\text {ade }}$ & $-28.17 \pm 7.27^{\mathrm{a}}$ & $-29.15 \pm 2.78^{a}$ \\
\hline 0.5 & 1.5 & $-36.35 \pm 3.95^{b}$ & $-35.32 \pm 3.74^{\mathrm{a}}$ & $-31.40 \pm 2.97^{\text {ade }}$ & $-31.71 \pm 6.11^{a}$ & $-23.72 \pm 2.01^{b}$ \\
\hline 0.5 & 2.0 & $-42.38 \pm 3.58^{c}$ & $-27.84 \pm 2.89^{b}$ & $-37.91 \pm 3.80^{\mathrm{b}}$ & $-39.13 \pm 7.15^{\mathrm{bcd}}$ & $-28.95 \pm 3.74^{\mathrm{a}}$ \\
\hline 1.0 & 1.0 & $-42.11 \pm 3.03^{c}$ & $-30.80 \pm 2.96^{\mathrm{b}}$ & $-34.37 \pm 2.43^{a b c}$ & $-38.53 \pm 3.91^{\mathrm{bcd}}$ & $-31.11 \pm 2.79^{\mathrm{ad}}$ \\
\hline 1.0 & 1.5 & $-46.71 \pm 2.91^{\mathrm{d}}$ & $-36.96 \pm 4.37^{a}$ & $-30.93 \pm 3.62^{\text {ade }}$ & $-38.18 \pm 3.78^{\mathrm{bcd}}$ & $-37.46 \pm 2.65^{c}$ \\
\hline 1.0 & 2.0 & $-47.09 \pm 4.54^{\mathrm{d}}$ & $-32.00 \pm 3.44^{c}$ & $-35.39 \pm 1.75^{b c}$ & $-44.22 \pm 6.98^{c}$ & $-36.86 \pm 3.15^{c}$ \\
\hline 1.5 & 1.0 & $-41.57 \pm 5.04^{c}$ & $-32.85 \pm 2.67^{c}$ & $-29.18 \pm 3.57^{\mathrm{e}}$ & $-26.45 \pm 4.58^{\mathrm{a}}$ & $-32.35 \pm 2.96^{\mathrm{d}}$ \\
\hline 1.5 & 1.5 & $-41.06 \pm 3.04^{c}$ & $-31.24 \pm 2.91^{\mathrm{bc}}$ & $-33.71 \pm 2.95^{\mathrm{acd}}$ & $-32.75 \pm 3.27^{\mathrm{ca}}$ & $-32.54 \pm 3.70^{\mathrm{d}}$ \\
\hline 1.5 & 2.0 & $-42.68 \pm 1.41^{c}$ & $-31.54 \pm 3.21^{b c}$ & $-30.38 \pm 2.39^{\text {ade }}$ & $-35.15 \pm 2.68^{\mathrm{cd}}$ & $-37.90 \pm 2.26^{c}$ \\
\hline
\end{tabular}

${ }^{\mathrm{a}-\mathrm{e}}$ Means $(n=10)$ in the same column with different superscripts are significantly different $(p<0.05)$. 
Table 3

Spreading coefficient $\left(W_{s}\right)$ obtained for solutions of $C$. pulcherrima galactomannan and glycerol on the analysed fruits.

\begin{tabular}{|c|c|c|c|c|c|c|}
\hline Gal. (w/v) & Glycerol (v/v) & Acerola & Cajá & Mango & Pitanga & Seriguela \\
\hline 0.5 & 1.0 & $-42.68 \pm 6.50^{\mathrm{a}}$ & $-27.69 \pm 3.73^{a}$ & $-51.29 \pm 4.14^{\mathrm{a}}$ & $-40.76 \pm 4.61^{a}$ & $-40.57 \pm 3.10^{a}$ \\
\hline 0.5 & 1.5 & $-39.83 \pm 5.95^{\mathrm{a}}$ & $-31.85 \pm 2.37^{\mathrm{b}}$ & $-65.48 \pm 4.57^{b}$ & $-35.54 \pm 5.39^{b}$ & $-36.33 \pm 3.39^{b}$ \\
\hline 0.5 & 2.0 & $-32.59 \pm 4.65^{b}$ & $-38.86 \pm 5.14^{\mathrm{ce}}$ & $-49.73 \pm 6.09^{a}$ & $-39.70 \pm 3.71^{\mathrm{a}}$ & $-40.66 \pm 2.82^{\mathrm{a}}$ \\
\hline 1.0 & 1.0 & $-44.70 \pm 4.42^{\mathrm{a}}$ & $-45.34 \pm 4.46^{\mathrm{d}}$ & $-68.82 \pm 6.38^{c}$ & $-47.91 \pm 6.25^{c}$ & $-45.27 \pm 3.17^{c}$ \\
\hline 1.0 & 1.5 & $-43.47 \pm 3.37^{\mathrm{a}}$ & $-45.08 \pm 3.54^{\mathrm{d}}$ & $-77.83 \pm 5.87^{d}$ & $-50.01 \pm 4.73^{c}$ & $-51.16 \pm 3.82^{\mathrm{d}}$ \\
\hline 1.0 & 2.0 & $-41.36 \pm 3.32^{\mathrm{a}}$ & $-47.48 \pm 4.31^{d}$ & $-66.24 \pm 7.72^{\mathrm{ec}}$ & $-57.02 \pm 2.86^{\mathrm{d}}$ & $-49.87 \pm 3.51^{\mathrm{d}}$ \\
\hline 1.5 & 1.0 & $-42.38 \pm 6.32^{\mathrm{a}}$ & $-40.06 \pm 6.04^{\mathrm{ce}}$ & $-64.36 \pm 7.84^{\mathrm{ec}}$ & $-41.88 \pm 4.30^{a}$ & $-41.44 \pm 4.72^{\mathrm{a}}$ \\
\hline 1.5 & 1.5 & $-40.60 \pm 3.77^{\mathrm{a}}$ & $-37.55 \pm 2.59^{c}$ & $-62.81 \pm 4.26^{\mathrm{e}}$ & $-43.01 \pm 5.46^{a}$ & $-42.29 \pm 3.37^{a}$ \\
\hline 1.5 & 2.0 & $-58.65 \pm 5.65^{c}$ & $-43.58 \pm 3.72^{\text {ced }}$ & $-45.20 \pm 4.49^{f}$ & $-58.83 \pm 5.31^{d}$ & $-47.81 \pm 3.59^{d}$ \\
\hline
\end{tabular}

${ }^{\mathrm{a}-\mathrm{f}}$ Means $(n=10)$ in the same column with different superscripts are significantly different $(p<0.05)$.

rola and seriguela). In the case of $C$. pulcherrima galactomannan the better value of $W_{s}$ in mango (lower polar component) was achieved for a galactomannan concentration of $1.5 \%$. These results are related to the polarity of the aqueous solutions; with the increase in the galactomannan concentration the polarity of the solutions decreases rendering them more able to coat non-polar surfaces (such mango surface).

Table 2 displays the values of $W_{s}$ obtained using the galactomannan of (AP). Acerola presents the best value of $W_{s}$ when coated with solutions containing $0.5 \%$ galactomannan and $1.0 \%$ glycerol, seriguela presents the best value with the same concentration of galactomannan and $1.5 \%$ of glycerol. For mango, pitanga and cajá solutions with $0.5 \%, 1.0 \%$ and $1.5 \%$ of galactomannan do not show a statistically significant difference, presenting good values of $W_{s}$ for the different concentrations of galactomannan and glycerol used.

When the galactomannan of $C$. pulcherrima (CP) was used, the values of $W_{s}$ (Table 3 ) present statistically significant differences for each fruit; a single solution was found in each case, having the lower value of $W_{s}$. In all cases, with the exception of mango (the best $W_{s}$ value was obtained with $1.5 \%$ of galactomannan) the best value of $W_{s}$ was obtained with solutions containing $0.5 \%$ of galactomannan.

The best coatings of $A$. pavonina and C. pulcherrima in terms of wettability (represented by the spreading coefficient $-W_{s}$ ) were subsequently analysed for water vapour, oxygen and carbon dioxide permeability, according to the below mentioned criteria.

\subsection{Water vapour permeability (WVP)}

The water vapour permeability is the most extensively studied property of edible films mainly because of the importance of the water in deteriorative reactions. Table 4 shows that the values of WVP change with the use of different concentrations of glycerol in the galactomannan solutions as for higher concentrations of glycerol an increase in WVP occurs. These differences are statistically significant when the plasticizer concentration is increased from $1.0 \%$ to $2.0 \%$. Gontard et al. (1993) explained that the effect of glycerol can be attributed to the hydrophilic properties of this compound which favour the adsorption of water molecules. Glycerol, through its plasticizing action, changes the polymer network creating mobile regions with larger interchain distances, promoting water clustering by competing with water at active sites of the polymer matrix and the formation of microcavities in the polymer network structure (Diab et al., 2001). The increase in WVP of edible films supported by increasing concentration of plasticizer has also been reported to happen in starch-based films (Mali et al., 2006), pullulan films (Diab et al., 2001), wheat gluten films (Gontard et al., 1993; Cherian et al., 1995), cellulose based films (Park and Chinnan, 1995) locust bean gum films (Aydinli and Tutas, 2000) and sodium caseinate/starch blends (Arvanitoyannis and Biliaderis, 1998).

An increase in the concentration of AP and CP galactomannans, for the same concentration of glycerol, corresponds to a decrease in WVP, possibly due a stronger gel network, where the polysaccharide molecules are closer, forming a more cohesive film structure. These changes present statistically significant differences when increasing of galactomannan concentration from $0.5 \%$ to $1.5 \%$ (Table 4 ). The formulations featuring lower values of WVP were: $0.5 \% \mathrm{CP}-1.0 \% \mathrm{Gly}, 1.5 \% \mathrm{CP}$ $2.0 \%$ Gly, $0.5 \%$ AP - 1.0\% Gly, $1.0 \%$ AP - $1.0 \%$ Gly and $1.5 \%$ AP 1.0 Gly.

The WVP values obtained for the galactomannans films are in agreement with those reported for other galactomannan and polysaccharide films. Aydinli and Tutas (2000) obtained WVP values ranging between 3.2 and $1.8\left(10^{-11} \mathrm{~g} \mathrm{~m}^{-1} \mathrm{~s}^{-1} \mathrm{~Pa}^{-1}\right)$ for films of locust bean gum $(\approx 1.0 \% \mathrm{w} / \mathrm{v})$ with polyethylene glycol $(\approx 0.4 \%$ and $1.7 \%(\mathrm{v} / \mathrm{v}))$. In other work, corn starch-based films (5\%) with glycerol $(1.4 \%)$ presented a WVP value of $8.7\left(10^{-11} \mathrm{~g} \mathrm{~m}^{-1} \mathrm{~s}^{-1} \mathrm{~Pa}^{-1}\right)$ (Garcia et al., 2006).

Table 4

Values of WVP, $\mathrm{O}_{2} \mathrm{P}, \mathrm{CO}_{2} \mathrm{P}$ and thickness of galactomannan films.

\begin{tabular}{|c|c|c|c|c|}
\hline Samples & $W V P \times 10^{-11}\left(\mathrm{~g} \mathrm{~m}^{-1} \mathrm{~s}^{-1} \mathrm{~Pa}^{-1}\right)$ & $\mathrm{O}_{2} \mathrm{P} \times 10^{-15}\left(\mathrm{~g} \mathrm{~m}\left(\mathrm{~Pa} \mathrm{~s} \mathrm{~m}^{2}\right)^{-1}\right)$ & $\mathrm{CO}_{2} \mathrm{P} \times 10^{-15}\left(\mathrm{~g} \mathrm{~m}\left(\mathrm{~Pa} \mathrm{~s} \mathrm{~m}^{2}\right)^{-1}\right)$ & Thickness $\times 10^{-4}(\mathrm{~m})$ \\
\hline 0.5CP-1.0Gly & $5.25 \pm 0.60^{\text {de }}$ & $0.97 \pm 0.02^{\mathrm{a}}$ & $37.57 \pm 2.75^{c}$ & $0.028 \pm 0.004^{\mathrm{a}}$ \\
\hline $0.5 \mathrm{CP}-1.5 \mathrm{Gly}$ & $6.25 \pm 0.20^{\mathrm{cd}}$ & $0.99 \pm 0.13^{\mathrm{ab}}$ & $28.81 \pm 3.08^{d}$ & $0.030 \pm 0.002^{\mathrm{ab}}$ \\
\hline 0.5CP-2.0Gly & $7.70 \pm 1.00^{\mathrm{ab}}$ & $1.10 \pm 0.14^{\mathrm{a}}$ & $4.10 \pm 1.67^{g}$ & $0.032 \pm 0.003^{\mathrm{ab}}$ \\
\hline 1.5CP-2.0Gly & $5.12 \pm 0.50^{\mathrm{de}}$ & $1.04 \pm 0.11^{\mathrm{a}}$ & $14.95 \pm 4.57^{\mathrm{ef}}$ & $0.035 \pm 0.005^{\mathrm{abc}}$ \\
\hline 0.5AP-1.0Gly & $5.33 \pm 0.01^{\mathrm{e}}$ & $0.50 \pm 0.01^{c}$ & $47.85 \pm 3.00^{\mathrm{b}}$ & $0.030 \pm 0.001^{\mathrm{a}}$ \\
\hline $0.5 \mathrm{AP}-1.5 \mathrm{Gly}$ & $6.98 \pm 0.27^{b}$ & $0.53 \pm 0.02^{c}$ & $17.40 \pm 1.21^{\mathrm{e}}$ & $0.031 \pm 0.003^{\mathrm{ab}}$ \\
\hline 0.5AP-2.0Gly & $8.10 \pm 0.50^{\mathrm{a}}$ & $0.86 \pm 0.02^{\mathrm{b}}$ & $10.94 \pm 1.44^{\mathrm{f}}$ & $0.032 \pm 0.003^{\mathrm{ab}}$ \\
\hline 1.0AP-1.0Gly & $5.02 \pm 0.03^{\mathrm{e}}$ & $0.37 \pm 0.02^{\text {de }}$ & $43.13 \pm 2.21^{\mathrm{b}}$ & $0.035 \pm 0.002^{\mathrm{bc}}$ \\
\hline 1.0AP-1.5Gly & $6.47 \pm 0.43^{\mathrm{bcd}}$ & $0.43 \pm 0.02^{\mathrm{d}}$ & $29.29 \pm 1.51^{d}$ & $0.034 \pm 0.002^{\mathrm{b}}$ \\
\hline 1.5AP-1.0Gly & $4.89 \pm 0.11^{\mathrm{e}}$ & $0.31 \pm 0.01^{\mathrm{e}}$ & $61.19 \pm 1.44^{\mathrm{a}}$ & $0.036 \pm 0.001^{c}$ \\
\hline 1.5AP-1.5Gly & $6.18 \pm 0.08^{c}$ & $0.41 \pm 0.12^{\text {cde }}$ & $47.08 \pm 1.94^{b}$ & $0.038 \pm 0.003^{c}$ \\
\hline 1.5AP-2.0Gly & $6.81 \pm 0.21^{\mathrm{bc}}$ & $0.49 \pm 0.03^{\mathrm{cd}}$ & $30.26 \pm 1.14^{\mathrm{d}}$ & $0.037 \pm 0.001^{c}$ \\
\hline
\end{tabular}

${ }^{\mathrm{a}-\mathrm{g}}$ Means $(n=10)$ in the same column with different superscripts are significantly different $(p<0.05)$. 


\subsection{Oxygen permeability $\left(\mathrm{O}_{2} \mathrm{P}\right)$}

Oxygen is the key factor for oxidation, which is responsible for changes in food odour, colour, flavour and nutrients deterioration. Therefore, films that provide a proper oxygen barrier can help in improving food quality and extending food shelf life. Table 4 presents the $\mathrm{O}_{2} \mathrm{P}$ as measured for the selected coatings of AP and CP. It is known that the increase in galactomannan concentration contributes to the decrease of permeability, while it is normally accepted that a higher concentration of glycerol increases $\mathrm{O}_{2} \mathrm{P}$ (as it does with WVP, as shown before) (Caner et al., 1998; Kester and Fennema, 1986). In general, the samples with higher concentration of plasticizer have higher values of $\mathrm{O}_{2} \mathrm{P}$ than the samples with a lower plasticizer concentration. These results can be explained by the apolar nature of the oxygen molecule that does not interact with the polar properties of the glycerol molecule, increasing the film permeability to the oxygen. Similar results were also obtained by Caner et al. (1998) and Kester and Fennema (1986) as the plasticizer decreases the intermolecular attractions between polymeric chains, facilitating the penetration of gas molecules. In the present case, the effect of the galactomannan source seems to have surpassed the effect of glycerol concentration, having statistically significant differences been found between $\mathrm{O}_{2} \mathrm{P}$ from films of AP and $\mathrm{CP}$ galactomannan. These differences might be explained by the different polymer chain constitution of the two galactomannans; AP galactomannan has a mannose/galactose ratio lower than that of CP galactomannan: 1.35 and 1.85 , respectively (Mikkonen et al., 2007; Cerqueira et al., 2009). The lowest values of $\mathrm{O}_{2} \mathrm{P}$ were obtained with three formulations: $1.0 \%$ AP - 1.0\% Gly, 1.5\% AP 1.0\% Gly and $1.5 \%$ AP - 1.5\% Gly.

\subsection{Carbon dioxide permeability $\left(\mathrm{CO}_{2} \mathrm{P}\right)$}

Carbon dioxide is very important to the respiration of living tissues and a higher value of $\mathrm{CO}_{2} P$ can delay fruits softening (Holcroft and Kader, 1999). Table 4 shows $\mathrm{CO}_{2} P$ values for the tested polysaccharide solutions. The results seem to indicate that solutions with a higher concentration of plasticizer produce films with a lower value of $\mathrm{CO}_{2} P$. The effect of glycerol concentration seems to be, by far, the most important one affecting $\mathrm{CO}_{2} \mathrm{P}$. An opposite effect of glycerol concentration has been noticed for $W V P$ and $O_{2} P$; those films showing a lower $\mathrm{O}_{2} \mathrm{P}$ are the ones that show a higher $\mathrm{CO}_{2} \mathrm{P}$. When glycerol concentration increases the WVP and $\mathrm{O}_{2} \mathrm{P}$ increased and $\mathrm{CO}_{2} \mathrm{P}$ decreased probably as a result of the polar and hydrogenbonding properties of the glycerol molecule. The highest value of $\mathrm{CO}_{2} \mathrm{P}$ was obtained with the formulation: $1.5 \% \mathrm{AP}-1.0 \% \mathrm{Gly}$.

Based on the previously presented criteria - high values of wettability, low water vapour permeability, a low $\mathrm{O}_{2} \mathrm{P}$ and a high $\mathrm{CO}_{2} \mathrm{P}$ - the following coating/film compositions were chosen to be the most adequate for each fruit: acerola - 0.5\% AP and 1.0\% Gly; cajá - 1.0\% AP and 1.0\% Gly; mango and pitanga - 1.5\% AP and $1.0 \%$ Gly; and seriguela $-0.5 \mathrm{CP}$ and 1.5 Gly (filled in gray in Table 4).

\subsection{Mechanical properties}

The values of TS and $E$ were measured in the films selected for each fruit (corresponding to the gray cells in Table 4). Fig. 1 shows that the values of TS increase with the increase in galactomannan concentrations for AP films. Comparing the TS values between films from AP and CP, Fig. 1 shows that the films of CP with a concentration of $0.5 \%$ of galactomannan and $1.5 \%$ of glycerol are not statistically different $(p>0.05)$ from AP films with concentrations of $1.5 \%$ of galactomannan and $1.0 \%$ of glycerol; this may be due to the less substituted structure of the galactomannan of CP (mannose/galactose ratio of 2.88) when compared with the structure of

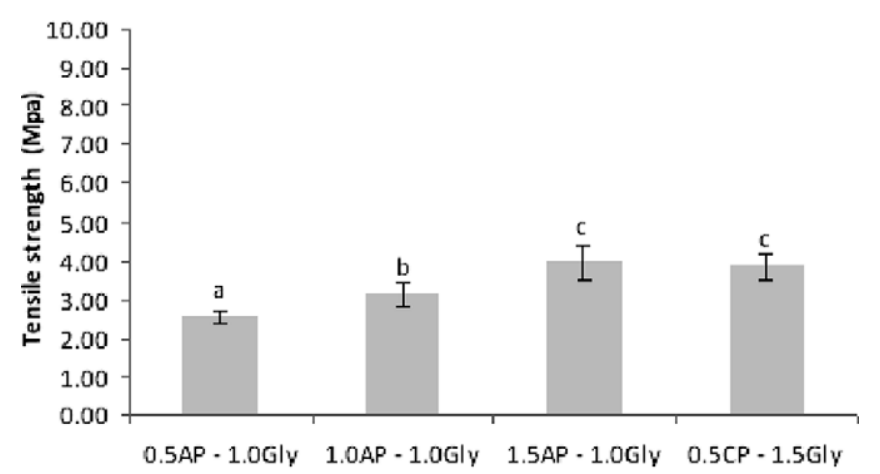

Fig. 1. Tensile at break for the film samples. ${ }^{\mathrm{a}-\mathrm{c}}$ Means $(n=3)$ with a different superscript are significantly different $(p<0.05)$.

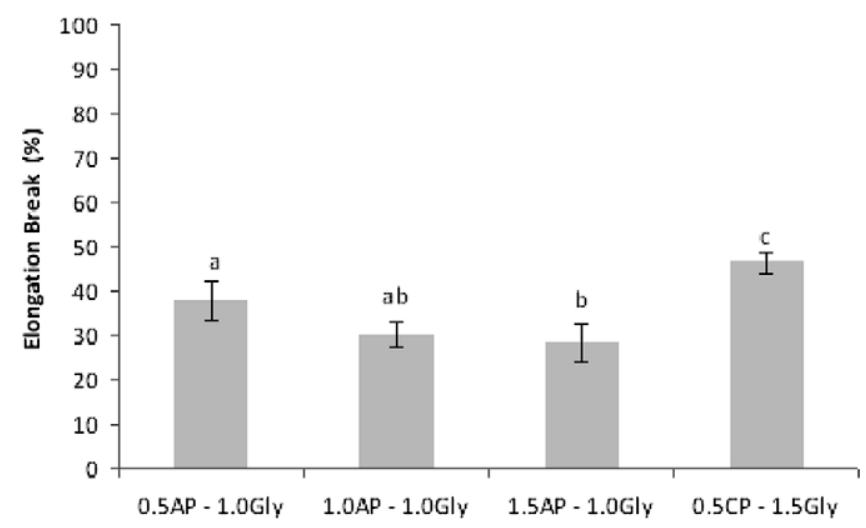

Fig. 2. Elongation at break for the film samples. ${ }^{\mathrm{a}-\mathrm{c}}$ Means $(n=3)$ with different superscripts are significantly different $(p<0.05)$.

AP (mannose/galactose ratio of 1.35); due to its less branched nature, the former may be more prone to establish intermolecular bonds than the latter, therefore providing a film with similar TS values despite the lower galactomannan concentration. Similar results were obtained by Mikkonen et al. (2007) when comparing the TS of locust bean gum (mannose/galactose ration of 3.5) and guar gum (mannose/galactose ration of 1.5 ) films. The $\mathrm{CP}$ film presents the higher value of $E$ (Fig. 2), which may be explained by the higher content of glycerol, but also by the more flexible, less substituted structure of the $\mathrm{CP}$ galactomannan when compared to that of the AP galactomannan; however, from the data it is not possible to conclude which of the two effects is the one most influencing the $E$ value. A similar trend has been reported by Mikkonen et al. (2007), who have shown that locust bean gum films are more flexible than the guar gum films.

The obtained values are in agreement with other reported studies that use polysaccharide films. Srinivasa et al. (2007) showed that chitosan films, with glycerol as plasticizer, have values of 14.14 MPa and $34.00 \%$, for TS and E, respectively. Garcia et al. (2006) showed that films with different ratios of corn starch, chitosan and glycerol have values ranging from 60.7 to $7.1 \mathrm{MPa}$ for TS and values ranging between 22.5 and $3.0 \%$ for $E$, with the film formed by corn starch and glycerol presenting TS and $E$ values closer to the films of galactomannan.

\section{Conclusion}

This work describes a methodology to optimize the composition of edible coatings to be applied in different tropical fruits taking into account parameters such as wettability, permeability to gases and mechanical properties. 
All fruits were shown to have the ability to participate in nonpolar interactions, as a consequence of the higher values of the dispersive component of the surface tension. Different formulations of galactomannan and glycerol showed good values of $W_{s}$, being the best values related to the dispersive component of the fruits surface.

The best coating formulation for each of the studied fruits was: acerola $-0.5 \%$ of $A$. pavonina and $1.0 \%$ of glycerol; cajá $-1.0 \%$ of $A$. pavonina and $1.0 \%$ of glycerol; mango and pitanga - $1.5 \%$ of $A$. pavonina and $1.0 \%$ of glycerol; and seriguela - $0.5 \%$ of $C$. pulcherrima and $1.5 \%$ of glycerol. These formulations should be either applied by immersion or sprayed on the fruits and let dry at room temperature during $3 \mathrm{~h}$.

It has been shown that these novel galactomannan extracted from AP and CP can be applied on the studied fruits based on their surface properties. Future work should include shelf-life studies in order to demonstrate the positive expected effects of the application of these coatings on the fruits: shelf-life extension with improved sensory quality.

\section{Acknowledgments}

The author M.A. Cerqueira is recipient of a fellowship from Fundação para a Ciência e Tecnologia (FCT, SFRH/BD/23897/2005) and A.M. Lima was the recipient of fellowship from $\alpha$ LFA VALNATURA Project of the Europe Aid Cooperation Office.

\section{References}

Arvanitoyannis, I., Biliaderis, C.G., 1998. Physical properties of polyol-plasticized edible films made from sodium caseinate and soluble starch blends. Food Chemistry 62 (3), 333-342.

ASTM D 3985-02 (2002). Standard test method for oxygen gas transmission rate through plastic film and sheeting using a coulometric sensor. In: Annual book of ASTM. Amer. Soc. for Testing \& Materials, Philadelphia, PA.

ASTM D 882-91, 1991. Standard Test Methods for Tensile Properties of Thin Plastic Sheeting. In: Annual book of ASTM standards. Amer. Soc. for Testing \& Materials, Philadelphia, PA.

Aydinli, M., Tutas, M., 2000. Water sorption and water vapour permeability properties of polysaccharides (Locust Bean Gum) based edible films. Food Science and Technology 33 (1), 63-67.

Busscher, H.J., Van Pelt, A.W., de Boer, P., de Jong, H.P., Arends, J., 1984. The effect of surface roughening of polymers on measured contact angles of liquids. Colloids and Surfaces 9 (4), 319-331.

Caner, C., Vergano, P.J., Wiles, J.L., 1998. Chitosan film mechanical and permeation properties as affected by acid, plasticizer and storage. Journal of Food Science 63 (6), 1049-1053.

Cerqueira, M.A., Pinheiro, A.C., Souza, B.W.S., Lima, A.M.P., Riberio, C., Miranda, C., Teixeira, J.A., Moreira, R.A., Coimbra, M.A., Gonçalves, M.P., Vicente, A.A., 2009. Extraction, purification and characterization of galactomannans from nontraditional sources. Carbohydrate Polymers 75 (3), 408-414.

Cherian, G., Gennadios, A., Weller, C., Chinachoti, P., 1995. Thermo-mechanical behavior of wheat gluten films: effect of sucrose, glycerin, and sorbitol. Cereal Chemistry 72 (1), 1-6.

Chien, P., Sheu, F., Yang, F., 2007. Effects of edible chitosan coating on quality and shelf life of sliced mango fruit. Journal of Food Engineering 78 (1), 225229.

Choi, W.Y., Park, H.J., Ahn, D.J., Lee, J., Lee, C.Y., 2002. Wettability of chitosan coating solution on "fuji" apple skin. Journal of Food Science 67 (7), 2668-2672.

Dang, K.T.H., Singh, Z., Swinny, E.E., 2008. Edible coatings influence ripening, quality, and aroma biosynthesis in mango fruit. Journal of Agricultural and Food Chemistry 56 (4), 1361-1370.

Dann, J.R., 1970. Forces involved in the adhesive process 1 . Critical surface tensions of polymeric solids as determined with polar liquids. Journal of Colloid and Interface Science 32 (2), 302-319.

Diab, T., Biliaderis, C.G., Gerasopoulos, D., Sfakiotakis, E., 2001. Physicochemical properties and application of pullulan edible films and coatings in fruit preservation. Journal of the Science of Food and Agriculture 81 (10), 988-1000.

Durango, A., Soares, N., Andrade, N., 2006. Microbiological evaluation of an edible antimicrobial coating on minimally processed carrots. Food Control 17 (5), 336341.

Farber, J.N., Harris, L.J., Parish, M.E., Beuchat, L.R., Suslow, T.V., Gorney, J.R., Garret, E.H., Busta, F.F., 2003. Microbiological safety of controlled and modified atmosphere packaging of fresh and fresh-cut produce. Comprehensive Reviews in Food Science and Food Safety 2 (1), 142-160.
Garcia, M.A., Pinotti, A., Zaritzky, N.E., 2006. Physicochemical, water vapor barrier and mechanical properties of corn starch and chitosan composite films. Starch 58 (9), 453-463.

Gontard, N., Duchez, C., Cuq, J.L., Guilbert, S., 1993. Water and glycerol as plasticizers affect mechanical and water barrier properties of an edible wheat gluten film. Journal of Food Science 58 (1), 206-211.

Guillard, V., Broyart, B., Bonazzi, C., Guilbert, S., Gontard, N., 2003. Preventing moisture transfer in a composite food using edible films: experimental and mathematical study. Journal of Food Science 68 (7), 2267-2277.

Holcroft, D.M., Kader, A.A., 1999. Controlled atmosphere induced changes in pH and organic acid metabolism may affect color of stored strawberries fruits. Postharvest Biology and Technology 17 (1), 19-32.

Kester, J.J., Fennema, O.R., 1986. Edible film and coatings: a review. Food Technology 40 (7), 47-59.

Kök, M.S., Hill, S.E., Mitchell, J.R., 1999. Viscosity of galactomannans during high temperature processing: influence of degradation and solubilisation. Food Hydrocolloids 13, 535-542.

Lee, L., Arul, J., Lencki, R., Castaigne, F., 1996. A review on modified atmosphere packaging and preservation of fresh fruits and vegetables: physiological basis and practical aspects (Part 2). Packaging Technology Science 9 (1), 1-17.

Lin, D., Zhao, Y., 2007. Innovations in the development and application of edible coatings for fresh and minimally processed fruits and vegetables. Comprehensive Reviews in Food Science and Food Safety 6 (3), 60-75.

Mali, S., Grossmann, M.V.E., 2003. Effects of yam starch films on storability and quality of fresh strawberries (Fragaria ananassa). Journal Agriculture and Food Chemistry 51 (24), 7005-7011.

Mali, S., Grossmann, M.V.E., Garcia, M.A., Martino, M.N., Zaritzky, N.E., 2006. Effects of controlled storage on thermal, mechanical and barrier properties of plasticized films from different starch sources. Journal of Food Engineering 75 (4), 453-460.

McHugh, T.H., Avena-Bustillos, R.J., Krochta, J.M., 1993. Hydrophilic edible film: modified procedure for water vapor permeability and explanation of thickness effects. Journal Food Science 58 (4), 899-903.

Mikkonen, K.S., Rita, H., Helén, H., Talja, R.A., Hyvönen, L., Tenkanen, M., 2007. Effect of polysaccharide structure on mechanical and thermal properties of galactomannan-based films. Biomacromolecules 8 (10), 3198-3205.

Newman, A.W., Kwok, D.Y., 1999. Contact angle measurement and contact angle interpretation. Advances in Colloid and Interface Science 81 (3), 167-249.

Park, H.J., Chinnan, M.S., 1995. Gas and water vapor barrier properties of edible films from protein and cellulosic materials. Journal Food Engineering 25 (4), 497-507.

Petersen, K., Nielsen, P.V., Bertelsen, G., Lawther, M., Olsen, M., Nilssonk, N.H., Mortenseny, G., 1999. Potential of biobased materials for food packaging. Trends in Food Science and Technology 10 (2), 52-68.

Phillips, C.A., 1996. Review: modified atmosphere packaging and its effects on the microbiological quality and safety of produce. Journal of Food Science Technology 31 (6), 463-479.

Reid, J.S.G., Edwards, M.E., 1995. Galactomannans and other cell wall storage polysaccharides in seeds. In: Stephen, A.M. (Ed.), Food Polysaccharides and Their Application (155-186). Marcel Dekker Inc., New York.

Ribeiro, C., Vicente, A.A., Teixeira, J.A., Miranda, C., 2007. Optimization of edible coating composition to retard strawberry fruit senescence. Postharvest Biology and Technology 44 (1), 63-70.

Rojas-Grau, M.A., Raybaudi-Massilia, R.M., Soliva-Fortuny, R.C., Avena-Bustillos, R.J., McHughb, T.H., Martín-Belloso, O., 2007. Apple puree-alginate edible coating as carrier of antimicrobial agents to prolong shelf-life of fresh-cut apples. Postharvest Biology and Technology 45 (2), 254-264.

Rulon, J., Robert, H., 1993. Wetting of low-energy surfaces. In: Berg, J.C. (Ed.) Wettability (4-73). Marcel Dekker Inc..

Song, B., Springer, J., 1996. Determination of interfacial tension from the profile of a pendant drop using computer-aided image processing. Journal Colloid Interface Science 184 (1), 64-76.

Srinivasa, P.C., Baskaran, R., Ramesh, M.N., Prashanth, K.V., Tharanathan, R.N., 2002 Storage studies of mango packed using biodegradable chitosan film. European Food Research Technology 215 (6), 504-508.

Srinivasa, P.C., Ramesh, M.N., Tharanathan, R.N., 2007. Effect of plasticizers and fatty acids on mechanical and permeability characteristics of chitosan films. Food Hydrocolloids 21 (7), 1113-1122.

Srivastava, M., Kapoor, V.P., 2005. Seed galactomannans: an overview. Chemistry and Biodiversity 2, 295-317.

Tanada-Palmu, P.S., Grosso, C.R., 2005. Effect of edible wheat gluten-based films and coatings on refrigerated strawberry (Fragaria ananassa) quality. Postharvest Biology and Technology 36 (2), 199-208.

Vieira, I.G.P.V., Mendes, F.N.P., Gallão, M.I., de Brito, E.S., 2007. NMR study of galactomannans from the seeds of mesquite tree (Prosopis juliflora (Sw) DC). Food Chemistry 101, 70-73.

Xu, S., Chen, X., Sun, D., 2001. Preservation of kiwifruit coated with an edible film at ambient temperature. Journal of Food Engineering 50 (4), 211-216.

Zagory, D., 1995. Principles and practice of modified atmosphere packaging of horticultural commodities. In: Farber, J.M., Dodds, K.L. (Eds.), Principles of Modified Atmosphere and Sous-Vide Product Packaging. Technomic Publishing Co. Inc., Lancaster, PA, pp. 175-204.

Zisman, W.A., 1964. Contact angle, wettability and adhesion. In: Fowkes, F.M. (Ed.) Advances in Chemistry, vol. 43. ACS, Washington, DC, pp. 1-51. 